\title{
Instruction Librarians: Acquiring the Proficiencies Critical to Their Work
} Diana Shonrock and Craig Mulder

\begin{abstract}
A bibliographic instruction librarian must possess many proficiencies. In an initial survey of members of the Bibliographic Instruction Section of the Association of College and Research Libraries, respondents evaluated the importance of eighty-four bibliographic instruction skills in thirteen categories. Skills in communication, instruction, and planning accounted for fourteen of the top twenty-five skills. In a second survey, respondents indicated how they had acquired the most important proficiencies and where they would have liked to have acquired them. For thirteen of the twenty-five skills, respondents preferred library school to other alternatives. For the other twelve skills, on-thejob training and other formal education were preferred.
\end{abstract}

ver the years, librarians have provided a variety of different types of library instruction. This study is based on the hypothesis that, although most literature suggests that some form of library instruction is necessary, most librarians don't have the skills needed to provide this instruction effectively. More and more positions in academic libraries require experience in, or the ability to provide, bibliographic instruction (BI). This article examines what skills BI librarians thought they needed to provide BI and to manage BI programs. It then examines what skills BI librarians thought they had, how they had acquired them, and how they thought they could best have acquired them.

\section{REVIEW OF RELATED RESEARCH}

Robert E. Brundin noted that, in 1975, only four library schools had special programs to educate librarians to teach library skills. ${ }^{1}$ Brundin found the major reason for the lack of programs was that learning theory and teaching methods are not ordinarily part of library school courses. In 1980, Maureen Pastine and Karen Seibert reported that eleven of the sixty-seven library schools accredited by the American Library Association offered a separate course in bibliographic instruction (BI). ${ }^{2}$ The number was the same when the Association for College and Research Libraries-Bibliographic Instruction Section, Education for Bibliographic Instruction Committee repeated the study in 1984. That study and a summary of similar research are discussed by Mary Ellen Larson and Ellen Meltzer in a 1987 journal article. ${ }^{3}$

Other research has examined what skills or knowledge are required by librarians and how these should be acquired. However, little, if any, research has been done on the specific skills related to bibliographic instruction in academic libraries. Much of the research done on the skills necessary for academic librarians is based on a survey of Association for Research Libraries (ARL) directors.

Diana Shonrock is Coordinator of General Reference Services, Parks Library, Iowa State University, Ames, Iowa 50011, and Craig Mulder is Assistant Director for Education, Welch Medical Library, Johns Hopkins University, Baltimore, Maryland 21205. 
Maurice P. Marchant and Nathan M. Smith analyzed the survey and found the need for an increase in instruction relating to analytical and human relation skills, as well as to online retrieval skills, systems analysis, and library automation. The data were distributed at a 1980 ARL meeting. In 1984, Marchant, Smith, and Laura F. Nielson repeated the study with public library directors and got similar results. ${ }^{5}$ The biggest weakness in these studies was that they surveyed only library directors, who are not usually the people hiring and supervising new librarians.

Another study, done by Charles D. Patterson and Donna W. Howell, looked at the educational preparedness and attitudes of librarians who participate in bibliographic instruction. Through a number of attitudinal questions, Patterson and Howell examined how librarians feel about teaching, how effective they consider themselves, and what problems they face. Librarians were asked about their educational backgrounds and previous teaching experiences, but not whether and how they had acquired specific skills. ${ }^{6}$

There are only a few studies directly related to the research described in this paper. One was done in 1986 by Ronald Powell and Sheila Creth. They asked similar questions, but directed them toward the whole range of skills and knowledge needed by librarians. They surveyed ARL librarians who had nine or fewer years of experience to determine their knowledge base in each of fifty-six areas, how important each was to effective job performance, where they had acquired the knowledge base, and where they felt it would best be acquired. In their study, bibliographic/library instruction skill ranked nineteenth in importance and fifteenth in perceived level of knowledge. Teaching methods often associated with bibliographic instruction ranked twentyeighth in importance and twenty-sixth in perceived level of knowledge.?

Also in 1986, Scott B. Mandernack completed a study of education and training needs specifically for bibliographic instruction librarians. He drew his sample from members of the Wiscon- sin Association of Academic Librarians. His responses indicated a need for future education in four areas: program development and management, teaching methodology, instructional development, and learning theory. New and experienced librarians indicated a preference for workshops and in-service training. ${ }^{8}$ The main limitation of Mandernack's study is the limited geographical focus.

In 1988, Powell examined where academic librarians had acquired their professional knowledge and where they thought that it would best have been acquired. Respondents in this study indicated that, although their skills had mostly been obtained in library schools and through on-the-job experience, they would have preferred to acquire these skills from continuing education and staff development programs. ${ }^{9}$

Mark Cain found in his 1988 survey of 1,771 librarians that approximately 42 percent of the respondents thought they had learned their library instruction skills on the job, but he did not look at what particular skills were needed or what those skills were. ${ }^{10}$

Barbara J.Smith conducted a survey of 120 Pennsylvania librarians in 1982 to determine the level of their education and training, their perceptions of the adequacy of training, and the need for additional training. She found that 61 percent of the respondents had training in learning theory, but only 17 percent had received that training in library school. Only 7 percent of the respondents indicated that they needed any special training to qualify for bibliographic instruction. Smith's results supported the perception that teaching was the best means of preparation. She concluded that the profession needed to support what it espouses and that teaching practicums should be part of the requirement to assure competency for instructional librarians."

The current study is significantly different from the Smith and Mandernank studies. This study took the approach of first identifying the skills considered most important for bibliographic instruction. Then respondents were asked about training for biblio- 
graphic instruction in the context of those specific skills, rather than in a general sense.

\section{RESEARCH PROBLEM AND QUESTIONS}

How do BI librarians acquire the skills needed to perform their jobs? How do they want to learn these skills? To answer these questions, the Association of College and Research Librarians Bibliographic Instruction Section's (BIS) Education for Bibliographic Instruction Committee decided to examine whether librarians involved with bibliographic instruction were acquiring the proficiencies needed for effective performance of their jobs. The initial research started with these questions:

- What proficiencies did survey respondents have?

- How important are the proficiencies for effective job performance?

- Where were those proficiencies acquired or developed?

- Where should the proficiencies have been acquired or developed?

\section{HISTORICAL DEVELOPMENT Deriving a List of Critical Proficiencies}

In 1983, the BIS Education for Bibliographic Instruction Committee formed a subcommittee to "attempt to identify the required proficiencies of BI librarians." 12 For the purpose of this study, BI included orientation to the library and its resources, course-integrated instruction, library research skills courses, online catalog and CD-ROM instruction, online searching demonstration, and term paper advisory services. "From the outset, the committee members agreed not to offer the final product as a 'standard' or even as a 'guideline' but rather as a means of communicating to library school faculty the preferred credentials for graduates planning to engage in bibliographic instruction activities. It was thought that the proficiencies might also be used in planning continuing education or in-service training programs."13

A list of eighty-four proficiencies was derived using three sources of information: a survey of a broad cross section of librarians active in bibliographic instruction, an analysis of the literature on this subject, and a review of the requirements indicated in position announcements for bibliographic instruction librarians. The initial study was completed with a report from the subcommittee to the BIS Executive Committee in 1986 . This report contained eighty-four proficiencies divided into two levels: those needed to conduct instructional activities (entry level) and those needed to administer a librarywide program (experienced level). The individual proficiencies were divided into thirteen subgroups.

\section{Developing the Methodology}

The eighty-four proficiencies identified by the subcommittee in 1986 became the basis for the authors' survey of BI librarians. The survey consisted of two sections and thirteen categories. For each proficiency, responses were requested in relation to the four research questions listed above.

For the purpose of this study, BI included orientation to the library and its resources, course-integrated instruction, library research skills courses, online catalog and CD-ROM instruction, online searching demonstration, and term paper advisory services.

In April 1987, a pretest of this survey was sent to seventeen librarians at the University of California's Berkeley and San Diego campuses. Eight surveys were returned. Using the answers and comments received, the questionnaire was revised and sent to BIS committee chairs in October 1987 for a second pretest. Next, an attempt was made to streamline the questionnaire. A recurring complaint concerned the length of the survey, which took thirty to forty-five minutes to complete. In response to the time concerns, the subcommittee decided to conduct the study in two phases. Phase 1 asked how important each of the proficiencies was to effective performance as 
TABLE 1

DEMOGRAPHICS OF RESPONDENTS

\begin{tabular}{|c|c|c|c|c|}
\hline \multirow[b]{3}{*}{$\begin{array}{l}\text { Current involvement in some kind of } \\
\text { bibliographic instruction. }\end{array}$} & \multirow{2}{*}{\multicolumn{2}{|c|}{$\begin{array}{c}\text { Phase 1 Survey } \\
\mathrm{n}=144\end{array}$}} & \multirow{2}{*}{\multicolumn{2}{|c|}{$\begin{array}{c}\text { Phase } 2 \text { Survey } \\
\qquad n=181\end{array}$}} \\
\hline & & & & \\
\hline & 128 & $89 \%$ & 156 & $84 \%$ \\
\hline \multicolumn{5}{|l|}{ Length of involvement in BI: } \\
\hline Less than 2 years & 10 & $7 \%$ & 17 & $10 \%$ \\
\hline 2-10 years & 76 & $53 \%$ & 98 & $54 \%$ \\
\hline More than 10 years & 54 & $38 \%$ & 66 & $36 \%$ \\
\hline No response & 2 & $1 \%$ & 0 & $0 \%$ \\
\hline \multicolumn{5}{|l|}{$\begin{array}{l}\text { The amount of time respondents currently spend } \\
\text { on bibliographic instruction: }\end{array}$} \\
\hline More than $50 \%$ & 7 & $5 \%$ & 12 & $7 \%$ \\
\hline $25-50 \%$ & 29 & $20 \%$ & 41 & $23 \%$ \\
\hline Less than $25 \%$ & 60 & $42 \%$ & 57 & $31 \%$ \\
\hline Administrative only & 34 & $24 \%$ & 45 & $25 \%$ \\
\hline No response/no time & 14 & $10 \%$ & 26 & $14 \%$ \\
\hline $\begin{array}{l}\text { Had teaching experience previous to receiving } \\
\text { their M.L.S. }\end{array}$ & 79 & $55 \%$ & 97 & $54 \%$ \\
\hline
\end{tabular}

a BI librarian. Phase 2 examined where the most important proficiencies were acquired and where librarians thought they should have been acquired.

\section{PHASE 1: WHAT ARE THE IMPORTANT PROFICIENCIES?}

\section{Design of the Survey}

For each of the proficiencies, the survey asked respondents, "In your experience, how important is this proficiency for the effective performance of a bibliographic instruction librarian?" The choices were: of no importance, of little importance, important, very important, essential, don't know. Additional questions concerned the respondent's involvement in bibliographic instruction and teaching experience prior to receiving a master's degree in library science. In April 1988, the committee sent 400 of the questionnaires to randomly selected members of BIS.

\section{Results}

Of the 400 questionnaires, 155 , or 39 percent, were returned and 144 , or 36 percent, were usable. The data were an- alyzed using the SPSS-PC software. Almost 90 percent of the respondents were involved in bibliographic instruction, and 25 percent spent at least a quarter of their time devoted to the area (see table 1).

For analysis purposes, the scale was converted to numerical equivalents: 1 = of no importance, 2 = of little importance, 3 = important, 4 = very important, and 5 = essential. "Don't know" and no response were treated as missing values. Of the eighty-four proficiencies, twentyfive had a mean greater than 4.0. (Refer to table 2 for a list of the top proficiencies and their means.)

Of the thirteen categories, those receiving the highest total means were communication skill, instructional ability, and planning ability. These three categories accounted for fourteen of the twenty-five most important proficiencies. Communication was clearly the most important category: six of the original eighty-four proficiencies were communication skills, and all six were included in the top twenty-five. In addition, the top three individual proficiencies were from the communication category. 
They were: the ability to organize and structure ideas logically (4.62), the ability to give clear and logical instructions (4.47), and the ability to deliver lectures, vary pace and tone, use eye contact, use appropriate gestures, and so forth (4.47).

This is in line with the Powell and Creth study, wherein "oral communications skills" tied for first in order of importance. ${ }^{14}$ Other main categories where numerous items received high means, above 4.0 , included the ability to write lesson plans, employ research and evaluation methodologies, plan a BI program, and promote a BI program. Many of these proficiencies could also be considered to fall within the realm of "research methods" and "teaching methods" from the Powell and Creth study.

Mandernack's study identified the most beneficial areas for future education and training to be program development and management, teaching methodology, instructional development, and learning theory. These are, in many ways, consistent with the findings of this study. ${ }^{15}$

The least important of the eighty-four proficiencies were research and evaluation skills, and budgeting abilities. They were: the ability to write funding proposals (2.89), understanding basic statistical concepts and methods (2.79), understanding of grantsmanship and external funding sources (2.77), understanding of validity and reliability measures for research use (2.65), and understanding of SPSS or other computerized statistical packages (2.19).

\section{PHASE 2: FINDING OUT WHERE LIBRARIANS LEARNED THESE PROFICIENCIES AND WHERE THEY WANTED TO LEARN THEM}

\section{Design of the Survey}

The subcommittee developed a questionnaire listing the twenty-five proficiencies with the highest means, the five proficiencies that scored the lowest on the first survey, and the four proficiencies with high standard deviations.

The first part of the questionnaire asked the respondent, "If you have this proficiency, indicate the most significant source from which you acquired it (check only one)." The second half of the questionnaire asked, "Indicate the most significant source from which you should acquire this proficiency." For each question, the following options were listed: library school, other formal education, continuing education, mentor/model, on-the-job, self-taught, and don't know/have.

Communication was clearly the most important category: six of the original eighty-four proficiencies were communication skills, and all six were included in the top twenty-five.

In May 1989, questionnaires were mailed to 400 randomly selected members of the Bibliographic Instruction section. This was a different group from the first survey. Of those mailed, 209, or 52 percent, were returned and 181 , or 45 percent, of them were usable. Eighty-four percent of the respondents were involved in $\mathrm{BI}$ and 90 percent had been in BI for at least two years. As with the first survey, over half of the respondents had taught previous to obtaining their master's degree (see table 1). The data were analyzed using Statview and FileMaker software on a Macintosh computer.

\section{Results: Where Did Librarians Learn These Proficiencies?}

Librarians overwhelmingly indicated three sources from which they had learned the proficiencies considered important for effective performance: on-thejob training, self teaching, and other formal education (see table 2). On-the-job training and self-teaching were the primary means of learning for eighteen of the proficiencies, and the secondary means for twenty-one of the proficiencies.

On-the-job training was an important source of acquiring proficiencies related to the environment in which the bibliographic instruction librarian works. For example, the ability to understand campus curricular needs is a skill that respondents felt they developed on the job. The workplace was also an important 
TABLE 2

TWENTY-FIVE MOST IMPORTANT PROFICIENCIES:

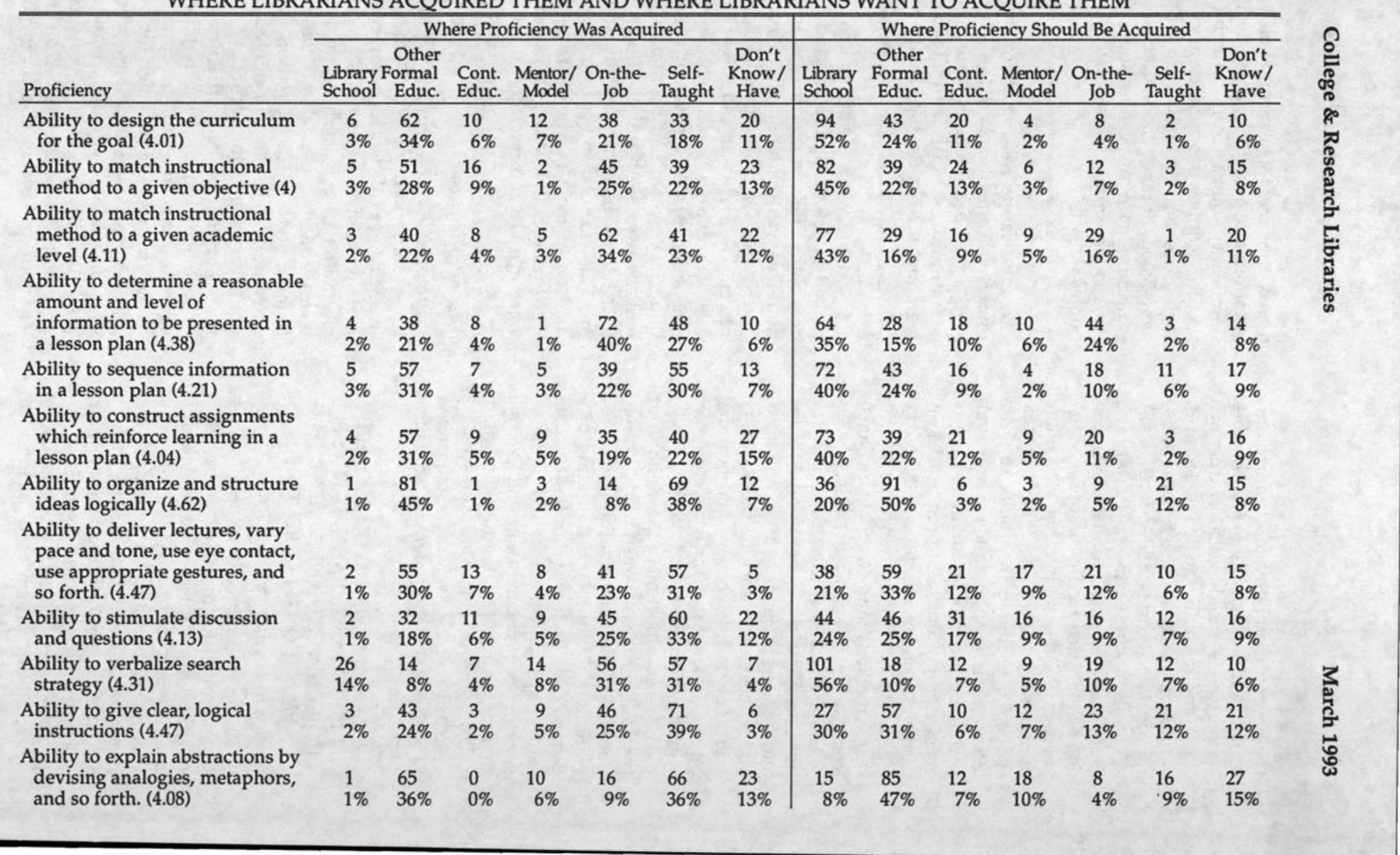


Proficiency (Mean)

Understanding of the structure of

information within various

disciplines and the categories of

tools necessary to use the

information (4.1)

Ability to develop a search strategy

$$
\text { (4.27) }
$$

Ability to understand campus curricular needs as part of the planning process (4.19)

Ability to relate aims of the institution to bibliographic instruction and BI to othe library services (4.09)

Ability to distinguish different levels of bibliographic instruction (4.11)

Ability to set priorities during planning (4.2)

Ability to inspire the confidence and respect of the library director and other supervisors (4.06)

Understanding of faculty priorities and value systems in order to promote a bibliographic instruction program (4.11)

Understanding of student assignments and the role of the library in completing these assignments (4.3)

Ability to be persistent and persuasive in "selling"

bibliographic instruction to administration and faculty (4.09)
Where Proficiency Was Acquired Where Proficiency Should Be Acquired

\section{Other}

Library Formal Cont. Mentor/ On- Self- Know/

School Educ. Educ. Model the-job Taught Have

\section{Othe}

Library Formal Cont. Mentor/ On- Self- Know/

School Educ. Educ. Model the-job Taught Have

\begin{tabular}{|c|c|c|c|c|c|c|c|c|c|c|c|c|c|}
\hline $\begin{array}{c}112 \\
62 \%\end{array}$ & $\begin{array}{c}14 \\
8 \%\end{array}$ & $\begin{array}{l}8 \\
4 \%\end{array}$ & $\begin{array}{l}2 \\
1 \%\end{array}$ & $\begin{array}{l}24 \\
13 \%\end{array}$ & $\begin{array}{c}13 \\
7 \%\end{array}$ & $\begin{array}{l}8 \\
4 \%\end{array}$ & $\begin{array}{l}149 \\
82 \%\end{array}$ & $\begin{array}{l}10 \\
6 \%\end{array}$ & $\begin{array}{l}4 \\
2 \%\end{array}$ & $\begin{array}{l}2 \\
1 \%\end{array}$ & $\begin{array}{l}7 \\
4 \%\end{array}$ & $\begin{array}{l}1 \\
1 \%\end{array}$ & $\begin{array}{l}8 \\
4 \%\end{array}$ \\
\hline $\begin{array}{l}80 \\
44 \%\end{array}$ & $\begin{array}{l}9 \\
5 \%\end{array}$ & $\begin{array}{c}14 \\
8 \%\end{array}$ & $\begin{array}{l}6 \\
3 \%\end{array}$ & $\begin{array}{l}45 \\
25 \%\end{array}$ & $\begin{array}{l}21 \\
12 \%\end{array}$ & $\begin{array}{l}6 \\
3 \%\end{array}$ & $\begin{array}{c}139 \\
77 \%\end{array}$ & $\begin{array}{c}15 \\
8 \%\end{array}$ & $\begin{array}{l}4 \\
2 \%\end{array}$ & $\begin{array}{l}2 \\
1 \%\end{array}$ & $\begin{array}{l}8 \\
4 \%\end{array}$ & $\begin{array}{l}3 \\
2 \%\end{array}$ & $\begin{array}{c}10 \\
6 \%\end{array}$ \\
\hline $\begin{array}{c}16 \\
9 \%\end{array}$ & $\begin{array}{c}10 \\
6 \%\end{array}$ & $\begin{array}{l}1 \\
1 \%\end{array}$ & $\begin{array}{l}10 \\
6 \%\end{array}$ & $\begin{array}{c}121 \\
67 \%\end{array}$ & $\begin{array}{c}14 \\
8 \%\end{array}$ & $\begin{array}{l}9 \\
5 \%\end{array}$ & $\begin{array}{l}52 \\
29 \%\end{array}$ & $\begin{array}{l}9 \\
5 \%\end{array}$ & $\begin{array}{l}6 \\
3 \%\end{array}$ & $\begin{array}{l}23 \\
13 \%\end{array}$ & $\begin{array}{l}80 \\
44 \%\end{array}$ & $\begin{array}{l}1 \\
1 \%\end{array}$ & $\begin{array}{l}10 \\
6 \%\end{array}$ \\
\hline $\begin{array}{c}13 \\
7 \%\end{array}$ & $\begin{array}{l}3 \\
2 \%\end{array}$ & $\begin{array}{l}4 \\
2 \%\end{array}$ & $\begin{array}{c}12 \\
7 \%\end{array}$ & $\begin{array}{c}121 \\
67 \%\end{array}$ & $\begin{array}{l}21 \\
12 \%\end{array}$ & $\begin{array}{l}7 \\
4 \%\end{array}$ & $\begin{array}{l}65 \\
36 \%\end{array}$ & $\begin{array}{l}1 \\
1 \%\end{array}$ & $\begin{array}{l}6 \\
3 \%\end{array}$ & $\begin{array}{l}22 \\
12 \%\end{array}$ & $\begin{array}{l}80 \\
44 \%\end{array}$ & $\begin{array}{l}0 \\
0 \%\end{array}$ & $\begin{array}{l}7 \\
4 \%\end{array}$ \\
\hline $\begin{array}{l}26 \\
14 \%\end{array}$ & $\begin{array}{l}5 \\
3 \%\end{array}$ & $\begin{array}{l}9 \\
5 \%\end{array}$ & $\begin{array}{l}5 \\
3 \%\end{array}$ & $\begin{array}{l}87 \\
48 \%\end{array}$ & $\begin{array}{l}42 \\
23 \%\end{array}$ & $\begin{array}{l}7 \\
4 \%\end{array}$ & $\begin{array}{l}131 \\
72 \%\end{array}$ & $\begin{array}{l}1 \\
1 \%\end{array}$ & $\begin{array}{l}7 \\
4 \%\end{array}$ & $\begin{array}{l}9 \\
5 \%\end{array}$ & $\begin{array}{c}14 \\
8 \%\end{array}$ & $\begin{array}{l}6 \\
3 \%\end{array}$ & $\begin{array}{c}13 \\
7 \%\end{array}$ \\
\hline $\begin{array}{c}13 \\
7 \%\end{array}$ & $\begin{array}{l}25 \\
14 \%\end{array}$ & $\begin{array}{l}8 \\
4 \%\end{array}$ & $\begin{array}{l}3 \\
2 \%\end{array}$ & $\begin{array}{l}54 \\
30 \%\end{array}$ & $\begin{array}{l}71 \\
39 \%\end{array}$ & $\begin{array}{l}7 \\
4 \%\end{array}$ & $\begin{array}{l}40 \\
22 \%\end{array}$ & $\begin{array}{l}37 \\
20 \%\end{array}$ & $\begin{array}{l}18 \\
10 \%\end{array}$ & $\begin{array}{c}13 \\
7 \%\end{array}$ & $\begin{array}{l}33 \\
18 \%\end{array}$ & $\begin{array}{l}24 \\
13 \%\end{array}$ & $\begin{array}{c}16 \\
9 \%\end{array}$ \\
\hline $\begin{array}{l}4 \\
2 \%\end{array}$ & $\begin{array}{l}4 \\
2 \%\end{array}$ & $\begin{array}{l}2 \\
1 \%\end{array}$ & $\begin{array}{l}7 \\
4 \%\end{array}$ & $\begin{array}{l}66 \\
36 \%\end{array}$ & $\begin{array}{l}84 \\
46 \%\end{array}$ & $\begin{array}{c}14 \\
8 \%\end{array}$ & $\begin{array}{c}14 \\
8 \%\end{array}$ & $\begin{array}{l}3 \\
2 \%\end{array}$ & $\begin{array}{l}6 \\
3 \%\end{array}$ & $\begin{array}{l}28 \\
15 \%\end{array}$ & $\begin{array}{l}52 \\
29 \%\end{array}$ & $\begin{array}{l}47 \\
26 \%\end{array}$ & $\begin{array}{l}31 \\
17 \%\end{array}$ \\
\hline $\begin{array}{l}6 \\
3 \%\end{array}$ & $\begin{array}{l}7 \\
4 \%\end{array}$ & $\begin{array}{l}0 \\
0 \%\end{array}$ & $\begin{array}{l}11 \\
6 \%\end{array}$ & $\begin{array}{l}114 \\
63 \%\end{array}$ & $\begin{array}{l}26 \\
14 \%\end{array}$ & $\begin{array}{c}17 \\
9 \%\end{array}$ & $\begin{array}{l}44 \\
24 \%\end{array}$ & $\begin{array}{l}3 \\
2 \%\end{array}$ & $\begin{array}{l}9 \\
5 \%\end{array}$ & $\begin{array}{l}29 \\
16 \%\end{array}$ & $\begin{array}{l}78 \\
43 \%\end{array}$ & $\begin{array}{l}2 \\
1 \%\end{array}$ & $\begin{array}{c}16 \\
9 \%\end{array}$ \\
\hline 12 & $\begin{array}{c}10 \\
6 \%\end{array}$ & $\begin{array}{l}0 \\
0 \%\end{array}$ & $\begin{array}{l}4 \\
2 \%\end{array}$ & $\begin{array}{c}130 \\
72 \%\end{array}$ & $\begin{array}{c}17 \\
9 \%\end{array}$ & $\begin{array}{l}8 \\
4 \%\end{array}$ & $\begin{array}{l}54 \\
30 \%\end{array}$ & $\begin{array}{l}2 \\
1 \%\end{array}$ & $\begin{array}{l}2 \\
1 \%\end{array}$ & $\begin{array}{c}15 \\
8 \%\end{array}$ & $\begin{array}{l}93 \\
51 \%\end{array}$ & $\begin{array}{l}2 \\
1 \%\end{array}$ & $\begin{array}{c}13 \\
7 \%\end{array}$ \\
\hline $\begin{array}{c}12 \\
7 \%\end{array}$ & $\begin{array}{l}2 \\
1 \%\end{array}$ & $\begin{array}{l}3 \\
2 \%\end{array}$ & $\begin{array}{l}10 \\
6 \%\end{array}$ & $\begin{array}{l}68 \\
38 \%\end{array}$ & $\begin{array}{l}65 \\
36 \%\end{array}$ & $\begin{array}{l}21 \\
12 \%\end{array}$ & $\begin{array}{l}49 \\
27 \%\end{array}$ & $\begin{array}{l}1 \\
1 \%\end{array}$ & $\begin{array}{l}24 \\
13 \%\end{array}$ & $\begin{array}{l}27 \\
15 \%\end{array}$ & $\begin{array}{l}36 \\
20 \%\end{array}$ & $\begin{array}{l}21 \\
12 \%\end{array}$ & $\begin{array}{l}23 \\
13 \%\end{array}$ \\
\hline
\end{tabular}




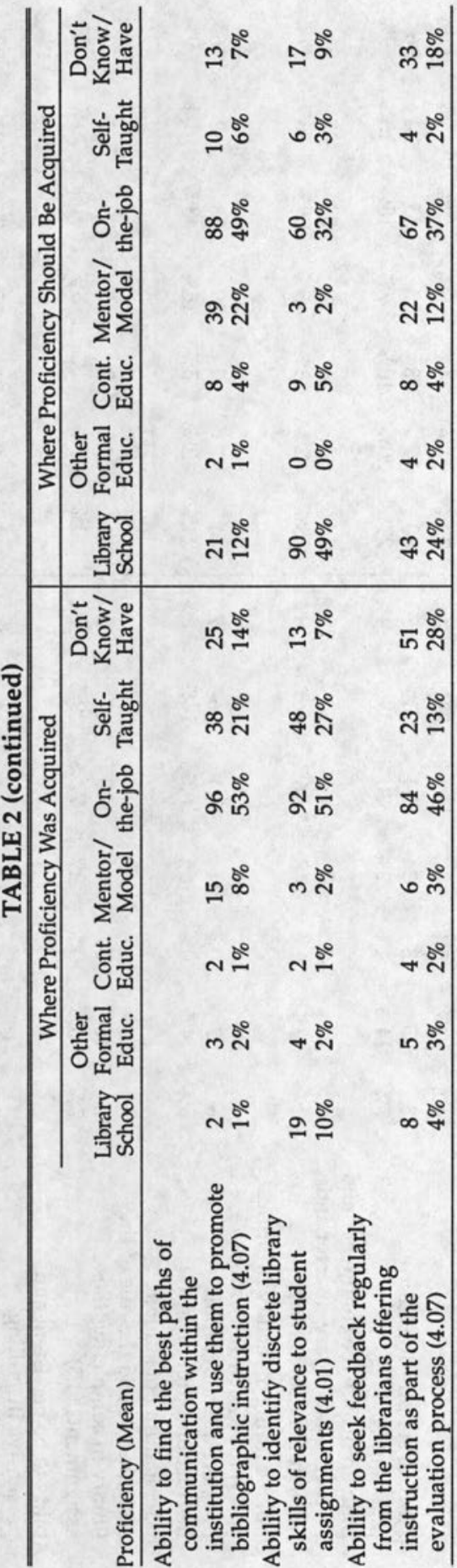

source of learning for teaching-related skills, such as the ability to determine a reasonable amount and level of information to be presented in a lesson plan.

Seven proficiencies were primarily self-taught. They were the abilities to:

- give clear and logical instructions

- explain abstractions by devising such things as analogies and metaphors

- stimulate discussion and questions, deliver lectures, vary pace and tone, use eye contact, use appropriate gestures, and so forth

- verbalize a search strategy

- inspire the confidence and respect of the library director and other supervisors

- set priorities during planning

Librarians learned five other proficiencies primarily in other formal education settings, including the most important proficiency: the ability to organize and structure ideas logically. The other four skills were the ability to design the curriculum for the goal, sequence information in a lesson plan, construct assignments which reinforce learning in a lesson plan, and match instructional method to a given objective.

Of the twenty-five proficiencies, respondents identified only two proficiencies as having been learned primarily in library school: understanding the structure of information within various disciplines and the categories of tools necessary to use the information, and the ability to develop a search strategy. Both skills concern content rather than teaching or planning skills.

The results were analyzed according to two demographic variables: amount of experience in $\mathrm{BI}$ and previous teaching experience. A chi-square test was run to determine if there was any difference in responses according to these factors. There was a significant relationship between teaching experience and whether the proficiency was learned via formal education for eight proficiencies (see table 3).

\section{Results: Where Do Librarians Feel They Should Learn These Proficiencies?}

All twenty-five proficiencies had library school, on-the-job training, or 
TABLE 3

PERCENTAGE OF RESPONDENTS WHO ACQUIRED PROFICIENCY

FROM OTHER FORMAL EDUCATION

ACCORDING TO PREVIOUS TEACHING EXPERIENCE

\begin{tabular}{lccc}
\hline & \multicolumn{3}{c}{ Previous Teaching Experience } \\
\cline { 2 - 4 } Proficiency & Yes & No & \\
\hline $\begin{array}{l}\text { Ability to design the curriculum for the goal } \\
\text { Ability to match instructional method to a given } \\
\text { objective }\end{array}$ & $51 \%$ & $15 \%$ & $\mathrm{p}<.01$ \\
$\begin{array}{l}\text { Ability to match instructional method to a given } \\
\text { academic level }\end{array}$ & $42 \%$ & $12 \%$ & $\mathrm{p}<.01$ \\
$\begin{array}{l}\text { Ability to determine a reasonable amount and } \\
\text { level of information to be presented in a lesson } \\
\text { plan }\end{array}$ & $30 \%$ & $13 \%$ & $\mathrm{p}<.10$ \\
$\begin{array}{l}\text { Ability to sequence information in a lesson plan } \\
\text { Ability to construct assignments which reinforce } \\
\text { learning in a lesson plan }\end{array}$ & $44 \%$ & $11 \%$ & $\mathrm{p}<.01$ \\
$\begin{array}{l}\text { Ability to deliver lectures, vary pace and tone, } \\
\text { use eye contact, use appropriate gestures, and } \\
\text { so forth. }\end{array}$ & $40 \%$ & $17 \%$ & $\mathrm{p}<.01$ \\
\begin{tabular}{l} 
Ability to stimulate discussion and questions \\
\hline
\end{tabular} & $26 \%$ & $17 \%$ & $\mathrm{p}<.01$ \\
\hline
\end{tabular}

other formal education as the preferred method of learning the skill, and twentytwo proficiencies had one of these three sources as the second preferred method. In terms of the preferred method of learning the skill, thirteen proficiencies had library school, seven had on-the-job training, and five had other formal education. For the second preferred method, nine proficiencies had library school, six had on-the-job training, and eight had other formal education.

Bibliographic instruction librarians felt that library school should be their primary place to learn thirteen of the twenty-five most important proficiencies (see table 4). Most of these proficiencies are related to curriculum and instructional design; these skills had been acquired via on-the-job training and other formal education.

For all twenty-five proficiencies, more respondents thought they should have learned the proficiency in library school than actually did learn them in library school. For eleven proficiencies, the difference between the percentage who acquired the skill in library school and the percentage who thought it should have been acquired there was greater than 25 percent. The five proficiencies for which the difference was the greatest all involved instructional development and teaching methods (see table 5).

On-the-job training and other formal education accounted for the other twelve proficiencies. There were seven proficiencies in which on-the-job training was the preferred means of learning. Five of these related to what could be called environmental skills, such as the ability to find the best paths of communication within the institution. The five proficiencies that respondents preferred to learn via other formal education related to communication.

Self-teaching was not an attractive learning option for respondents. Seven proficiencies had been learned primarily from self-teaching, but self-teaching was not a preferred learning method for any proficiency.

\section{SUMMARY AND CONCLUSIONS}

Three of the four most important groups of proficiencies require skills important in all areas of librarianship: communication, planning, and promotion. 


\section{TABLE 4}

PERCENTAGE OF RESPONDENTS WHO FEEL THE PROFICIENCY SHOULD BE LEARNED AT LIBRARY SCHOOL

Understanding of the structure of information within various disciplines and the categories of tools necessary to use the information

Ability to develop a search strategy

Ability to distinguish different levels of bibliographic instruction

Ability to verbalize search strategy

Ability to design the curriculum for the goal

Ability to identify discrete library skills of relevance to student assignments

Ability to match instructional method to a given objective

Ability to match instructional method to a given academic level

Ability to construct assignments which reinforce learning in a lesson plan

Ability to sequence information in a lesson plan

Ability to determine a reasonable amount and level of information to be presented in a lesson plan

Ability to be persistent and persuasive in "selling" bibliographic instruction to administration and faculty

TABLE 5

PROFICIENCIES WITH GREATEST DIFFERENCE

IN WHETHER THE PROFICIENCY WAS ACQUIRED IN LIBRARY SCHOOL AND WHETHER IT SHOULD HAVE BEEN ACQUIRED THERE

\begin{tabular}{lcc}
\hline Proficieny & $\begin{array}{c}\text { \% of respondents } \\
\text { who acquired it in } \\
\text { library school }\end{array}$ & $\begin{array}{c}\text { \% of respondents } \\
\text { who feel it should be } \\
\text { acquired in library } \\
\text { school }\end{array}$ \\
\hline $\begin{array}{l}\text { Ability to distinguish different levels of bibliographic } \\
\text { instruction }\end{array}$ & 14 & 72 \\
$\begin{array}{l}\text { Ability to design the curriculum for the goal } \\
\text { Ability to match instructional method to given } \\
\text { objective }\end{array}$ & 3 & 52 \\
$\begin{array}{l}\text { Ability to verbalize search strategy } \\
\text { Ability to match instructional method to a given } \\
\text { academic level }\end{array}$ & 3 & 45 \\
\hline
\end{tabular}

The question is whether these skills are unique to librarianship, or whether students should have acquired them before they entered library school. Larson and Meltzer state in their article, "The skills needed to participate in user education programs are those essential to effective librarianship: an organized, logical approach to problem-solving; an understanding of the literature structure in the various disciplines; and the ability to communicate this knowledge articulately and concisely."16

Respondents thought that library school should be the major source of learning BI skills. Many of the proficiencies that the respondents found they most lacked and thought that they should have acquired in library school were related to material that could be learned in one or two instructional methods and curriculum development classes. 
What are the alternatives for teaching these proficiencies? Although library school is the preferred method for learning, many respondents also favored on-the-job training and other formal education.Perhaps prospective BI librarians in library schools could be offered classes through the university's school of education.

Why haven't library schools offered more BI instruction? Two possible reasons are proposed by other authors. Brundin maintains that not enough students have instruction as a career goal to make inclusion feasible. He quotes Anne Roberts as saying too many library school faculty advocate the role of reference librarian as a provider of information and not as an educator. ${ }^{17}$ Aluri and Engle also note that the major problem with BI, according to library school faculty, is that its theoretical base lies not only in librarianship but also in theories of learning and instructional design. ${ }^{18}$

\section{All twenty-five proficiencies had library school, on-the-job training, or other formal education as the preferred method of learning the skill, and twenty-two proficiencies had one of these three sources as the second preferred method.}

It is important to note that the current study measured the perception of librarians, not whether library schools actually did or did not offer education in these proficiencies. Library schools may include communication, planning, and promotion in other courses, such as management. Aluri and Engle, in the conclusion to their report on the drafting of the proficiencies list, suggest that "it is possible that the integrated approach will do more to foster support for BI and to prepare effective BI librarians than the separate course so strongly supported by those who became our BI experts without it."19

Another issue to consider is that some of the proficiencies considered important by respondents may not be considered important by employers, and vice versa. Herbert S. White and Marion
Paris found that directors of large academic libraries recommended sixteen courses for the preparation of entry-level professionals, including ten primarily bibliography and reference courses, two in collection development, two in cataloging, one in management, and one with automation. The directors, however, did not recommend special area courses, such as BI courses..$^{20}$ What must be taken into consideration, though, is that directors may not be responsible for hiring and supervising BI librarians, and therefore, may not be as aware of the need for BI skills as were the participants in this study.

\section{RECOMMENDATIONS FOR FURTHER STUDY}

Continuing education may have fared poorly in this study because it was not well defined and not distinguishable from on-the-job training and self-teaching. It can be presented in a number of formats, ranging from half-day in-house workshops to semester-long courses. If asked in a different way, librarians may have felt differently about continuing education. Jane Robbins, in her article on a continuing education program at the University of Wisconsin, Madison, emphasizes the need for formal programs of continuing education, particularly as the positions of librarians change and they begin to move into middle management positions. ${ }^{21}$ John Corbin includes as one of five roles for library schools the need to better tailor the continuing education offerings to the needs of the libraries. ${ }^{2}$ Perhaps in this regard, too, the authors need to look at ways to meet the mandates of the BI librarians responding to this study.

In addition, it is hard to ignore the contrary information reported in the 1988 Powell study concerning the perceived need for more continuing education. In his 1989 comments, Herbert S. White also emphasizes the importance of continuing education when he says, "Continuing education is a normal and recognized process in any discipline that considers itself a profession." ${ }^{23}$ Surely one of the things that this study brings out is the fact that practicing librarians 
have put great emphasis on the role of the library school. Perhaps this indicates the need to look at other types of education and make them viable options, if indeed the library schools cannot, as White says, "justify the lengthening of a program without promise of return on the investment." ${ }^{24}$ A question that needs to be examined is whether BI can be learned via continuing education. Can it be learned in one- and two-day courses? Is continuing education for BI effective?

The discussion of the issue of skills has not waned. In a recent article on the educational requirements for future librarians, Anne Woodsworth and June Lester included the ability to "provide instruction to ensure information literacy." ${ }^{25}$ If librarians are to have these skills, it must be determined what those skills or competencies are and how they can best be obtained.
It might be useful to replicate this study by surveying the individuals considered by their peers to be excellent BI librarians. Their view of the important skills and how they should be learned may differ from the vision of the more general audience.

Perhaps it is time to examine the standards of library schools and their curriculum, the types of continuing education available from all sources, and other sources of skill updating. In his study of the future of librarianship, Allen B. Veaner indicated that it is time to examine these issues. ${ }^{26}$ Above all, it is important that BI librarians obtain the skills they need, because BI librarians have become highly visible members of the library profession and much has been written in the past couple of years on the importance of such positive visibility for librarians.

\section{REFERENCES AND NOTES}

1. Robert E. Brundin, "Education for Instructional Librarians: Development and Overview," Journal of Education for Library and Information Science 25 (Winter 1985): 177-89.

2. Maureen Pastine and K. Siebert, "Update on the Status of Bibliographic Instruction in Library School Programs." Journal of Education for Librarianship 21 (Fall 1980): 169-71.

3. Ellen Larson and Ellen Meltzer, "Education for Bibliographic Instruction," Journal of Education for Library and Information Science 28 (Summer 1987): 9-16.

4. Maurice P. Marchant and Nathan M. Smith, "The Research Library Director's View of Library Education," College \& Research Libraries 43 (Nov. 1982): 437-44.

5. Nathan M. Smith, Maurice P. Marchant, and Laura F. Nielson, "Education for Public and Academic Librarians: A View from the Top," Journal of Education for Librarianship 28 (Spring 1984): $233-45$.

6. Charles D. Patterson and Donna W. Howell, "Library User Education: Assessing the Attitudes of Those Who Teach," RQ 29 (Summer 1990): 513-24.

7. Ronald Powell and Sheila Creth. "Knowledge Bases and Library Education," College \& Research Libraries 47 (Jan. 1986): 16-27.

8. Scott B. Mandernack, "An Assessment of Education and Training Needs for Bibliographic Instruction Librarians," Journal of Education for Library and Information Science 30 (Winter 1986): 193-201.

9. Ronald R. Powell, "Sources of Professional Knowledge for Academic Librarians," College \& Research Libraries 49 (July 1988): 332-40.

10. Mark Cain, "Academic Librarians: Who Are We?" Journal of Academic Librarianship 14 (Nov. 1988): 292-96.

11. Barbara J. Smith, "Background Characteristics and Education Needs of a Group of Instruction Librarians in Pennsylvania," College \& Research Libraries 43 (May 1982): 199-207.

12. Barbara Wittkopf, "Proficiencies for BI Librarians: Who Defines Them?" Research Strategies 8 (Summer 1990): 102-3.

13. Ibid.

14. Powell and Creth, "Knowledge Bases," 22.

15. Mandernack, "Assessment of Education and Training Needs," 199.

16. Larson and Meltzer, "Education for Bibliographic Instruction," 15.

17. Brundin, "Education for Instructional Librarians," 180. 
18. Rao Aluri and June Lester Engle, "Bibliographic Instruction and Library Education," in Bibliographic Instruction: The Second Generation, ed. by Constance A. Mellon, (Littleton, Colo.: Libraries Unlimited, 1987), 113.

19. Ibid.

20. Herbert S. White and Marion Paris, "Employer Preferences and the Library Education Curriculum" Library Quarterly 55 (Jan. 1985): 1-33.

21. Jane Robbins, "Research Skills for Research Librarians: A Report on and Examples from an Educational Program," Journal of Academic Librarianship 15, no.1 (Mar. 1989): 4-6.

22. John Corbin, "The Education of Librarians in an Age of Information Technology," Journal of Library Administration 9, no.4 (1988): 77-87.

23. Herbert S. White, "Follow the Yellow Brick Road to Library Oz," Library Journal 114 (Sept. 15, 1989): 93-94.

24. Ibid.

25. Anne Woodsworth and June Lester, "Educational Imperatives of the Future Research Library: A Symposium." Journal of Academic Librarianship 17 (Sept. 1991): 204-15.

26. Allen B. Veaner, "1985 to 1990: The Next Decade in Academic Librarianship, Part I," College \& Research Libraries 46 (July 1985): 209-29; and Allen B. Veaner, "1985 to 1990: The Next Decade in Academic Librarianship, Part II," College \& Research Libraries 46 (July 1985): 295-308.

\section{IN FORTHCOMING ISSUES OF COLLEGE \& RESEARCH LIBRARIES}

Preservation Analysis and the Brittle Book Problem in College Libraries: The Identification of Research-level Collections and Their Implications

Janet Gertz, Charlotte B. Brown, Jane Beebe, Daria D'Arienzo, Floyd Merritt, and Lynn Robinson

The 1986 College Library Standards: Application and Utilization

David B. Walch

Interdisciplinary Work and the Information Search Process: A Comparison of Manual and Online Searching

Laura M. Bartolo and Timothy D. Smith

The Managerial Decision Styles of Academic Library Directors

Terrence Mech

A Library Committee on Diversity and Its Role in a Library Diversity Program

Kristin H. Gerhard and Jeanne M. K. Boydston

Job Satisfaction of Academic Librarians: An Examination of the Relationships between Satisfaction, Faculty Status, and Participation

Bonnie Horenstein

Networks, Hypertext and Academic Information Services: Some Longer-range Implications Ross Atkinson

Collective Bargaining and Faculty Status: A Twenty-year Case Study of Wayne State

University Librarians

Lothar Spang 


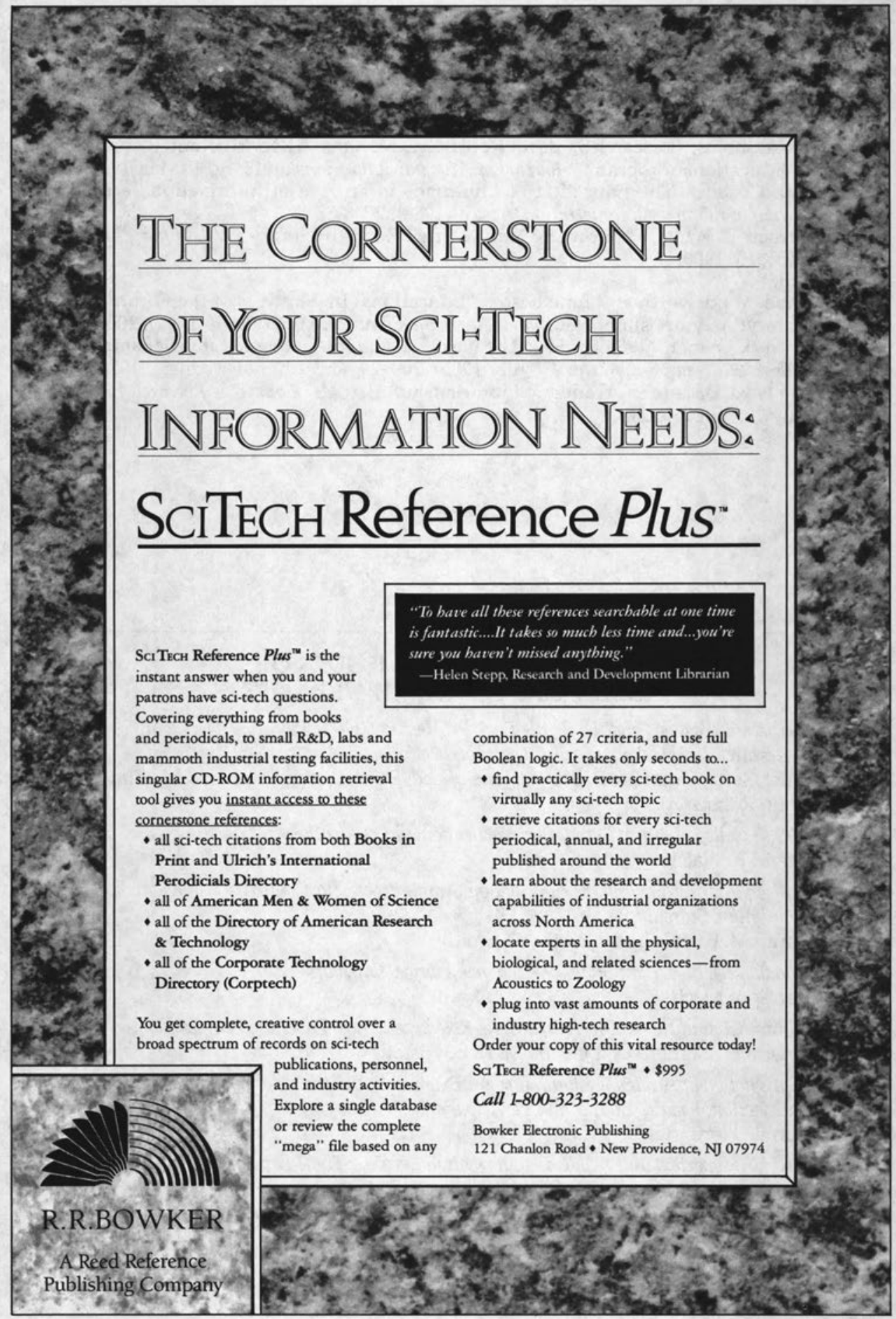

